\title{
Identification of Heat-Induced Proteomes in Tomato Microspores Using LCM- Proteomics Analysis \\ Li H' ${ }^{1}$, Zhu $Y^{1}$, Rangu $\mathbf{M}^{1}$, Wu $X^{1}$, Bhatti $\mathbf{S}^{1}$, Zhou $\mathbf{S}^{1^{*}}$, Yang $\mathbf{Y}^{2}$, Fish $\mathrm{T}^{2}$ and Thannhauser TW ${ }^{*}$
}

${ }^{1}$ Department of Agricultural and Environmental Sciences, College of Agriculture, Tennessee State University, Nashville, TN, USA

${ }^{2}$ R.W. Holley Center for Agriculture and Health, USDA-ARS, Cornell University, Ithaca, NY, USA

\begin{abstract}
Pollen development is highly susceptible to heat stress (HS) and the production of inviable pollen causes reduction in seed- and fruit-set in plants. This study was carried out to identify HS-induced pollen proteins and the associated biological processes in tomato (Solanum lycopersicum). Tomato 'Micro-Tom' plants were incubated under $32^{\circ} \mathrm{C} / / 22^{\circ} \mathrm{C}$ (day/night, $12 / 12 \mathrm{~h}$ ) for two weeks for heat treatment, and the non-treated control plants were incubated for the same time period at $25^{\circ} \mathrm{C} / 22^{\circ} \mathrm{C}$. Flower buds of $5 \mathrm{~mm}$ in length were confirmed to contain the heat sensitive uninucleate microspores. Pollen cells were harvested using laser capture microdissection (LCM) and protein was extracted using a one-step method under high pressure and vacuum. Approximately 60,000 LCMharvested microspore cells yielded about $18-20 \mu \mathrm{g}$ proteins. The tandem mass tags (TMT) proteomics analysis identified a total of 6018 proteins, 4784 proteins were quantified, 37 proteins were identified as HS up-regulated significantly changed proteins (SCPs), and 83 proteins as HS down (dn)-regulated SCPs. Further analysis using the plant MetGenMap system showed that the HS up-regulated SCPs were enriched in the heat acclimation, pollen wall formation, protein folding/refolding gene ontology (GO) biological processes, and the HS dn-regulated SCPS were placed in the carbohydrate catabolism and de-novo protein biosynthesis $\mathrm{GO}$ terms. Biological processes such as mitosis, resistance to oxidative stresses, and carbohydrate and lipid metabolic processes contain both the HS up-, and dn-regulated SCPs. These results indicate that the LCM-TMT proteomics workflow is highly efficient in the identification of HS-induced pollen proteomes. These HS induced SCPS will be used for exploring heat tolerance of tomato pollens. The proteomics data are available via ProteomeXchange with identifier PXD010218.
\end{abstract}

Keywords: LCM-TMT-proteomics; Microspores; Tomato; Pollen; Viability; Heat stress; Protein functional classification

\section{Introduction}

Tomato (Solanum lycopersicum L.) is a major crop worldwide. In the US, tomato is the Nation's fourth most popular fresh-market vegetable behind potatoes, lettuce, and onions in terms of consumption, according to the data from the United States Department of Agriculture, Economic Research Service [1]. For tomato to properly set fruits it requires $21^{\circ} \mathrm{C}$ to $22^{\circ} \mathrm{C}$ at night and $24^{\circ} \mathrm{C}$ to $25^{\circ} \mathrm{C}$ during the day $[2,3]$. Tomato pollen production and viability is highly vulnerable to higher temperature $\left(32 / 26^{\circ} \mathrm{C}\right.$ day and night) [4]. Hot summers can result in up to $70 \%$ losses in tomato yield due to failure in the production of viable pollens, and several earlier studies have indicated that the reduced carbohydrate contents in the developing anthers are in part responsible for this biological phenomenon [5-7].

In angiosperms, mature pollens are developed through a series of successive phases from microsporocytes [8]. During the microsporogenesis stage, the diploid pollen mother cells (PMC) undergo meiosis to give rise to four haploid microspores (tetrads). As pollen enters the microgametogenesis stage, these microspore cells are released from the tetrad, and the free microspores enlarge and undergo polarization and asymmetric mitosis to form desiccated pollen grains [9]. Quantitative proteomics analysis in tomato and Arabidopsis thaliana showed each of these distinct pollen development stages (pollen mother cell, tetrad, microspore, polarized microspore, and mature pollens) expresses the cell-specific proteomes, and each stage shows a specific reprogramming of the proteome [10-12].

The sensitivity of pollen to heat stress (HS) varies over the course of pollen development, and the most heat sensitive timing occurs from meiotic process of microsporocytes, at the young microspore stage (uninucleate stage of microspore) to during late pollen development (pollen mitosis) $[10,13]$. Heat stress induces reorganization of the transcriptome, proteome and metabolome [14]. A recent study indicated that the response of pollen to elevated temperature was mainly regulated at the proteome level [15]. Therefore profiling quantitative proteomic changes in each type of these heat sensitive pollen cells will lead to a systematic understanding of pollen developmental processes under the HS conditions.

Cell-specific quantitative proteomics analysis requires the preparation of a homogenous cell population. In one of the widely used methods, anthers are normally removed from the flower buds and soaked in a buffer to release pollen cells, and high purity pollen samples are obtained by differential centrifugation [10,15]. The fluorescence-activated cell sorting (FACS) method is also used to separate pollen cells into subpopulations and for the removal of non-pollen debris tissues [16]. These pollen harvest methods have the possibility to induce physical or chemical stresses during handling of flower buds, centrifugation, and the FACS process, which may reduce the power of the quantitative proteomics in the identification of HS related proteins.

To avoid these unintended effects during sample preparation, we have

*Corresponding author: Zhou S, Department of Agricultural and Environmental Sciences, College of Agriculture, Tennessee State University, 3500 John Merritt Blvd, Nashville, TN 37209, USA, Tel: +1-615-963-2465; E-mail: zsuping@tnstate.edu

Thannhauser TW, R.W. Holley Center for Agriculture and Health, USDA-ARS, Cornell University, Ithaca, NY 14853, USA, Tel: +1-607-255-8808; E-mail: tt34@cornell.edu

Received July 20, 2018; Accepted July 31, 2018; Published August 03, 2018

Citation: Li H, Zhu Y, Rangu M, Wu X, Bhatti S, et al. (2018) Identification of Heat-Induced Proteomes in Tomato Microspores Using LCM- Proteomics Analysis. Single Cell Biol 7: 173. doi:10.4172/2168-9431.1000173

Copyright: (C) $2018 \mathrm{Li} \mathrm{H}$, et al. This is an open-access article distributed under the terms of the Creative Commons Attribution License, which permits unrestricted use, distribution, and reproduction in any medium, provided the original author and source are credited. 
developed a laser capture microdissection (LCM)-proteomics analysis workflow. Flower buds were fixed immediately after harvest to stop any further biological activities. A single-step protein extraction method was developed for the LCM pollen tissue samples, which significantly improved protein extraction efficiency by eliminating tissue grinding and protein purification steps. Here, we report a tandem mass tag (TMT)-quantitative proteomics analysis of the LCM- harvested pollen samples from heat treated tomatoes. The roles of the heat-induced significantly changed proteins (SCPs) in heat tolerance/acclimations of developing pollen were discussed.

\section{Materials and Methods}

\section{Tomato heat treatments}

Tomato 'Micro-Tom' plants were grown in a greenhouse $\left(25 / 22^{\circ} \mathrm{C}\right)$ with no supplemental light till flower buds emerged (approximately 40-45 days). Plants were transferred into a preheated growth chamber and exposed to $32^{\circ} \mathrm{C} / 22^{\circ} \mathrm{C}$ (day/night, $12 / 12 \mathrm{~h}$ ) for two weeks. Untreated plants were kept in a growth chamber for the same time period at $25^{\circ} \mathrm{C}$ $122^{\circ} \mathrm{C}$. Tomato flowers under the heat treatment condition produced a smaller number of total and viable pollens, which confirmed the presence of HS (unpublished data, Zhu and Zhou, 2018, Tennessee State University). Flower buds were harvested from the heat treated or at the same time from control plants. According to Bokszczanin and Fragkostefanakis [17] tomato flower buds of 4-6 mm in length should contain pollen at the meiotic stage/microspore mother cell stage [17]. In this study, we only selected flower buds of $5 \mathrm{~mm}$ in length.

\section{Preparation of pollen samples and laser capture microdissection (LCM)}

The LCM sample preparation followed a method described before with minor modification [18]. Tomato flower buds were submerged in a fixative solution containing $75 \%(\mathrm{v} / \mathrm{v})$ ethanol and $25 \%(\mathrm{v} / \mathrm{v})$ acetic acid, at a 1:10 volume ratio of tissue to fixative on ice. Fixative was infiltrated into the tissue under vacuum for $15 \mathrm{~min}$ on ice and then replaced with fresh solution, before incubating at $4^{\circ} \mathrm{C}$ overnight. Tissues were transferred into a phosphate-buffered saline buffer containing $10 \%$ sucrose and the Halt protease inhibitor cocktail (Thermo Fisher, NY) and infiltrated for $2 \times 10 \mathrm{~min}$. Finally, tissues were infiltrated twice in the same buffer except increasing sucrose to $20 \%$ (w/v). Flower buds were imbedded in optimal cutting temperature (O.C.T.) compound (TissuePlus; FisherScientific, NY) in $10 \mathrm{~mm} \times 10 \mathrm{~mm} \times 5 \mathrm{~mm}$ TissueTeck Cryomold (Sakura, USA) and frozen into blocks under liquid nitrogen. Tissues were cut into $20 \mathrm{um}$ thick sections at $-20^{\circ} \mathrm{C}$ using a cryostat (Leica CM1950; Leica, Germany). These frozen slides were washed in $75 \%$ ethanol for $10 \mathrm{~min}$ and then dipped in absolute ethanol. Microspores inside the pollen sacs were picked using the PALM MicroBeam laser microdissection system (ZEISS, Germany). For each replicate sample, approximately 60,000 cells were collected.

\section{Protein extraction and tandem mass tags (TMT) labeling}

Proteins were extracted in a Pressure Cycling Technology (PCT) buffer comprising of $20 \mathrm{mM}$ HEPES, pH 8.0, $4 \mathrm{M}$ urea, 2\% SDS, 2 mM EDTA on a Barocycler (2320 EXT; Pressure Biosciences Inc, NY). The LCM capture cap was washed in $45 \mu \mathrm{l}$ PCT buffer. Solutions containing the LCM cells were collected by centrifugation and transferred to a $50 \mu \mathrm{l}$ PCT microtube. Protein extraction was performed by running 60 cycles under $45 \mathrm{kPsi}$ pressure at $25^{\circ} \mathrm{C}$. After completion of the cycles, the protein extract solution was transferred to a $1.5 \mathrm{ml}$ Eppendorf tube and centrifuged at $13,000 \mathrm{rpm}$ for $10 \mathrm{~min}$ at $4^{\circ} \mathrm{C}$. Supernatant containing proteins was transferred to a clean tube. Protein concentration was measured using Qubit Protein Assay Kit (Fisher Scientific), on a Qubit 3.0 Fluorometer (Life Technologies Corporation, NY). Proteins (18 $\mu \mathrm{g}$ each sample) were reduced with tris (2-carboxyethyl) phosphine (TCEP) and cysteines were blocked with methyl methanethiosulfonate (MMTS). After removal of sodium dodecyl sulfate (SDS) and urea using S-TRAP Micro-Kit (PROTIFI, NY, USA ), on-column trypsin digestion was carried out using the sequencing grade modified trypsin (Promega, WI) at $35^{\circ} \mathrm{C}$ for $16 \mathrm{~h}$. Tryptic peptides were eluted by centrifugation $(8,000 \mathrm{rpm}$ for $0.5 \mathrm{~min})$ in $40 \mu \mathrm{L} 50 \mathrm{mM}$ triethylamonium bicarbonate (TEAB) buffer, $40 \mu \mathrm{L} 0.2 \%$ formic acid, and finally $40 \mu \mathrm{L} 50 \%$ acetonitrile and $0.2 \%$ formic acid. Elutes were combined and dried down under vacuum. The tryptic peptides were reconstituted in $50 \mu \mathrm{l}$ of $50 \mathrm{mM}$ TEAB and labeled with TMT tags $(126,127,128$ for the three heattreated replicates, and 129,130, 131 for the three non-treated control replicates), using the TMT six-plex label reagent set (Thermo Fisher). After pooling of the labeled peptides, unbound tags, SDS, and salts were removed using the Oasis MCX 1cc $30 \mathrm{mg}$ Extraction Cartridges 9 (Waters, MA). Peptides were eluted twice in $75 \% \mathrm{ACN} / 10 \% \mathrm{NH}_{4} \mathrm{OH}$ and dried-down under vacuum.

\section{High $\mathrm{pH}$ reverse phase (hpRP) fractionation and nano liquid chromatography and mass spectrometry analysis (LC-MS/MS)}

The hpRP chromatography was carried out using a Dionex UltiMate 3000 HPLC system with the built-in micro fraction collection option in its autosampler and UV detection (Sunnyvale, CA). Specifically, the TMT 6-plex tagged tryptic peptides were reconstituted in buffer A (20 $\mathrm{mM}$ ammonium formate, $\mathrm{pH} 9.5$ in water), and loaded onto an XTerra MS C18 column $(3.5 \mu \mathrm{m}, 2.1 \times 150 \mathrm{~mm})$ from Waters (Milford, MA) with $20 \mathrm{mM}$ ammonium formate (NH4FA), $\mathrm{pH} 9.5$ as buffer A and $80 \%$ acetonitrile/20\% $20 \mathrm{mM} \mathrm{NH4FA} \mathrm{as} \mathrm{buffer} \mathrm{B.} \mathrm{The} \mathrm{LC} \mathrm{was} \mathrm{performed}$ using a gradient from $10-45 \%$ of buffer $B$ in 30 minutes at a flow rate 200 $\mu \mathrm{L} / \mathrm{min}$. Forty-eight fractions were collected at 1 minute intervals and pooled into a total of 6 fractions based on the UV absorbance at $214 \mathrm{~nm}$ and with multiple fraction concatenation strategy. All of the fractions were dried and reconstituted in $40 \mu \mathrm{L}$ of $2 \% \mathrm{ACN} / 0.5 \%$ FA for nano LCMS/MS analysis. Nano LC-MS/MS analysis was carried out using an Orbitrap Fusion (Thermo Scientific, CA) mass spectrometer equipped with nano ion source using high energy collision dissociation (HCD). The Orbitrap is coupled with the UltiMate3000 RSLCnano (Dionex, Sunnyvale, CA). Each reconstituted fraction $(8 \mu \mathrm{L})$ was injected onto a PepMap C-18 RP nano trap column $(3 \mu \mathrm{m}, 75 \mu \mathrm{m} \times 20 \mathrm{~mm}$, Dionex $)$ with nanoViper Fittings at $20 \mu \mathrm{L} / \mathrm{min}$ flow rate for on-line desalting and then separated on a PepMap C-18 RP nano column $(3 \mu \mathrm{m}, 75 \mu \mathrm{m} \times 15$ $\mathrm{cm}$ ), and eluted in a $120 \mathrm{~min}$ gradient of $5 \%$ to $38 \% \mathrm{ACN}$ in $0.1 \% \mathrm{FA}$ at $300 \mathrm{~nL} / \mathrm{min}$, followed by a $7-\mathrm{min}$ ramping to $95 \% \mathrm{ACN}-0.1 \% \mathrm{FA}$ and a 7 -min hold at $95 \%$ ACN-0.1\% FA. The column was re-equilibrated with $2 \% \mathrm{ACN}-0.1 \%$ FA for 20 min prior to the next run. The Orbitrap Fusion was operated in positive ion mode with nano spray voltage set at $1.6 \mathrm{kV}$ and source temperature at $275^{\circ} \mathrm{C}$. External calibration for FT, IT and quadrupole mass analyzers was performed. An internal calibration was performed using the background polysiloxane ion signal at $\mathrm{m} / \mathrm{z}$ 445.120025. The instrument was operated in data-dependent acquisition (DDA) mode using the FT mass analyzer to select precursor ions followed by "Top 3 second" data-dependent HCD-MS/MS scans for precursor ions with 2-7 charges/ion above a threshold ion count of 10,000 with normalized collision energy of $37.5 \%$. MS survey scans were carried out at a resolving power of 120,000 (fwhm at $\mathrm{m} / \mathrm{z} 200$ ), for the mass range of $\mathrm{m} / \mathrm{z} 400-1600$ with $\mathrm{AGC}=3 \mathrm{e} 5$ and Max IT $=50$ ms. MS/MS scans were carried out at 50,000 resolution with AGC $=1 \mathrm{e} 5$, Max IT $=120 \mathrm{~ms}$ and with Q isolation window $(\mathrm{m} / \mathrm{z})$ at 1.6 for the mass range $\mathrm{m} / \mathrm{z}$ 105-2000. Dynamic exclusion parameters were set at 1 
Citation: Li H, Zhu Y, Rangu M, Wu X, Bhatti S, et al. (2018) Identification of Heat-Induced Proteomes in Tomato Microspores Using LCM- Proteomics Analysis. Single Cell Biol 7: 173. doi:10.4172/2168-9431.1000173

within 50s exclusion duration with $\pm 10 \mathrm{ppm}$ exclusion mass width. All data were acquired under Xcalibur 3.0 operation software and Orbitrap Fusion Tune 2.0 (Thermo-Fisher Scientific).

\section{Data processing protocol}

All MS and MS/MS raw spectra from each set of TMT 6-plex experiments were processed and database searched using Sequest HT software within Proteome Discoverer 2.2 (PD 2.2; Thermo Scientific) against tomato protein database version ITAG3.20. The default search settings used for 6-plex TMT quantitative processing and protein identification in PD 2.2 searching software were: two mis-cleavages for full trypsin with fixed carbamidomethyl of cysteine, fixed 6-plex TMT modifications on lysine and $\mathrm{N}$-terminal amines and variable modifications of methionine oxidation and deamidation on asparagine and glutamine residues. The peptide mass tolerance and fragment mass tolerance values were $10 \mathrm{ppm}$ and $50 \mathrm{mDa}$, respectively.

Identified peptides were filtered for a maximum 0.05\% FDR using the Percolator algorithm in PD 2.2. Peptide confidence was set to high. The TMT 6-plex quantification method within PD 2.2 was used to calculate the reporter ratios. Only peptide spectra containing all reporter ions were designated as "quantifiable spectra" and used for peptide/protein quantitation. The mass spectrometry proteomics data have been deposited to the ProteomeXchange Consortium via the PRIDE partner repository with the dataset identifier PXD010218, under project title "Identification of heat-induced proteomes in tomato microspores using laser capture microdissection proteomics analysis" ( http://www.ebi. ac.uk/pride).

\section{Identification of significantly changed proteins (SCPs) and protein functional analysis}

In the quantitative proteins analysis, only proteins quantified with two or more peptides were included. These proteins were first fitted to a principal component analysis (PCA) to determine if there was a systemic change from heat-treated to non-treated groups. Then the abundance ratios (treated/control) of these proteins were converted to $\log 2$ fold values which were fitted to a normal distribution [19]. The threshold criteria for Significantly Changed Proteins (SCPs) were set as: abundance ratio value (treated/control) higher than 2.0 standard deviation $( \pm 2 \mathrm{SD})$ which was derived from the normal distribution test; proteins quantified with two or more unique peptides; and the Abundance Ratio P-Value (Treatment/Control) $\leq 0.5$ in the PD 2.2 report. Gene Ontology (GO) functional classification of these SCPs was identified using the Plant MetGenMAP system [20]. Additional literature searches were conducted to verify and supplement this database-generated information.

\section{Microscopic analysis of pollen developmental stages}

Frozen tissue slides (before and after LCM) were stained with 4',6-diamidino-2-phenylindole (DAPI) and observed under an Olympus Widefield Imaging System (Metamorph) using 10x and 40x objective magnification and UV excitation filters to confirm the developmental stage of pollen cells.

\section{Statistical analysis}

The SAS version 9.0 software (SAS Inc., Cary, NC, USA) was used to perform the analysis of PCA and normal distribution test of quantitative proteomics data.

\section{Results}

The microscopic analysis showed that the LCM-harvested microspores from heat-treated and non-heat-treated conditions were all at the uninucleate stage (Figure 1). These results confirmed that these LCMharvested microspores from both treatment conditions were at the same heat sensitive developmental stage. Using LCM, the microspore cells inside the pollen sacks were harvested (Figure 1). Approximately 60,000 pollen cells were collected in each replicate sample which

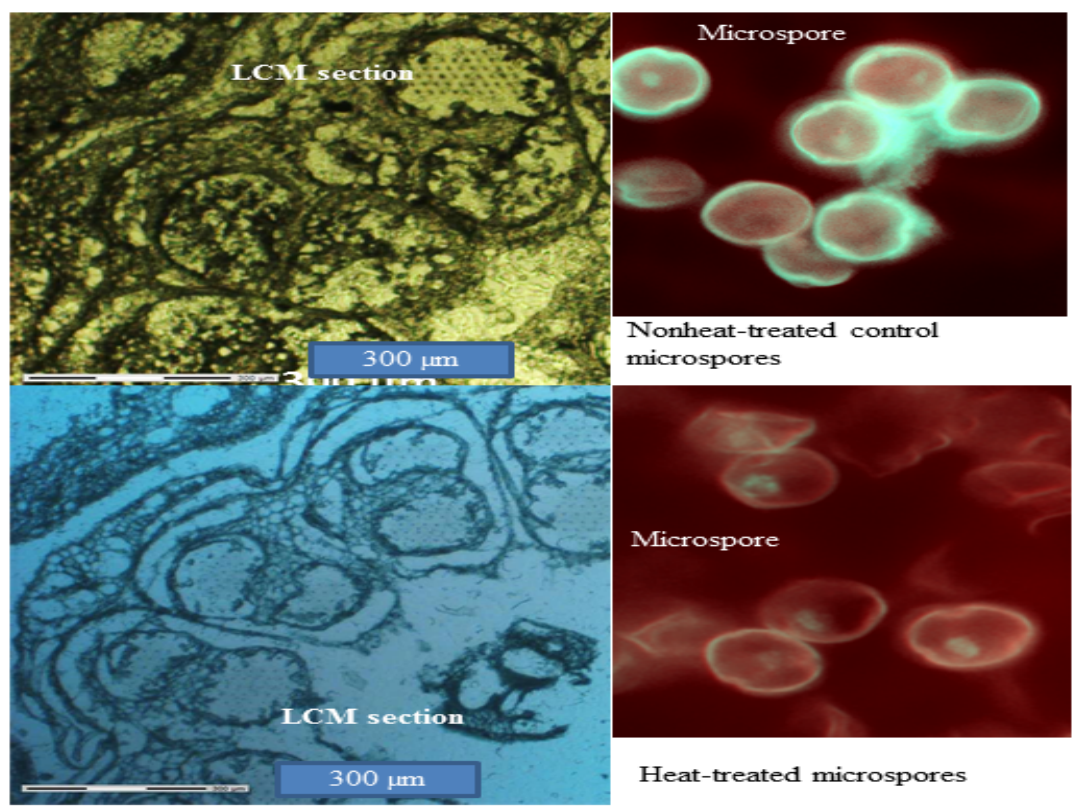

Figure 1: Microscopic analysis of pollen developmental stages of LCM harvested tissues. Pollen nuclei were stained with DAPI and visualized under Olympus BX50 upright microscope using oil immersion 40X objective lenses. Images of the DAPI stained nuclei (blue) were overlapped with background (red) tissues using Metamorph acquisition program ( Right). Microspores were harvested with LCM (Left)". 
yielded about 18-20 $\mu \mathrm{g}$ proteins. The proteomics analysis identified a total of 6018 proteins and 4784 proteins were quantified. In the PCA analysis of proteins that were quantified with two and more unique peptides, the three heat treated biological replicate samples were clustered in a separate component from the three non-treated control replicate samples (Supplemental Figure S1) This PCA analysis indicated a systemic change in the microspore proteomes from heat treated to non-heat treated conditions. The log2 fold values (treated/control) of proteins in the normal distribution test produced a standard deviation at 0.26 . The SCPs were selected for proteins with $\log 2$ fold $>0.52$, or $<-0.52$, which equals to $>1.43$, or $<0.70$ of the Abundance Ratio (Treatment/Control) in the PD 2.2. From these quantified proteins, 37 proteins were identified as HS-up-regulated SCPs, and 83 HS-dnregulated SCPs (Table 1).

\section{Gene Ontology (GO) functional classification of heat-induced significantly changed proteins (SCPs)}

The SCPs protein accessions were uploaded to the Plant MetGenMap system to obtain their annotated protein identities (SupplementaL Tables S1 and S2). Functional classification analysis showed that a large number of proteins were classified under the cellular metabolic and primary metabolic processes for either Heat up- or dn-regulated SCPs (Figure 2, Supplemental Table S3). These results indicate that the tomato microspores have undergone a dynamic alteration in metabolic pathways under heat treatment conditions. Only the up-regulated SCPs were assigned to the following processes: Heat Acclimation, Pollen Cell Wall, Protein Folding/refolding, and G2/M-specific positive regulation of cyclin-dependent protein kinase activity (FDR $\mathrm{P}<0.05$ in the enriched GO-term test). Only the dn-regulated SCPs were assigned to myo-inositol transport, sucrose metabolic process, cellular metabolic compound salvage, amino acid catabolic process, Golgi organization, pyruvate metabolic process, and glycolysis processes.

\section{Heat-induced SCPs associated with microspore development into viable pollen grains}

The development of microspore into viable pollen is affected by the species and contents of carbohydrates. Under HS, the acid invertase activity was inhibited which resulted in low soluble sugar level and inviable pollen $[7,21]$. In the heat treated tomato microspores, five dn-regulated SCPs were classified into the starch metabolic process; they are glucose-1-phosphate adenylyltransferase (Solyc07g019440), which catalyzes the first committed step toward the synthesis of starch in plants, and beta-fructofuranosidase (also known as acid invertase) ( Solyc10g085640, Solyc10g085650, Solyc09g010090; Solyc09g010080), which catalyzes sucrose (sucrose-6P) or stachyose degradation to glucose-6P. Both HS up- and dn-regulated SCPs were placed in the following groups: DNA replication, DNA recombination, mitosis, pollen expansion, and development of pollen wall (Table 2).

\section{Heat-induced SCPs involved in proteome homeostasis}

We have selected the top ten biological processes that would affect cellular/subcellular proteome composition in the heat-treated microspores (Figure 3, Supplemental Table S4). The HS-induced SCPs (up or $\mathrm{dn}$ ) were classified into groups including protein posttranslational modification, protein targeting/localization, proteolysis, protein metabolic process, and protein complex assembly processes. Moreover, the HS-up-regulated SCPs were more enriched in the processes for protein folding/refolding and protein ubiqutination (Figure 3A). These two processes have a key role in maintaining functional protein homeostasis. The HS down-regulated SCPs were clustered into protein translation and ribosome biogenesis, which could lead to a reduced rate of protein biogenesis (Figure 3B).

\section{Discussion}

In this study, we have developed a workflow for LCM-quantitative proteomics of microspore cells. Microspores at the most-heat sensitive uninucleate stage were harvested using LCM. Proteins were extracted from the LCM samples in one step which significantly simplified the process and also considerably reduced protein loss compared to those multiple-step protein extraction methods.

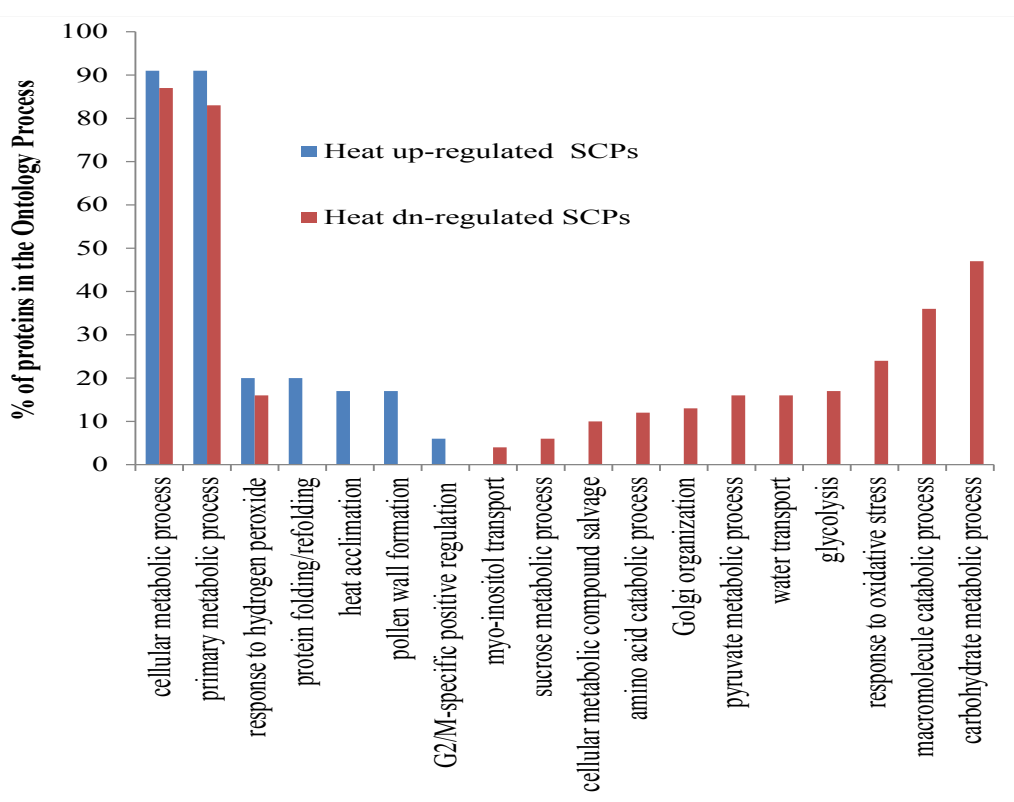

Figure 2: Distribution of proteins up- (blue) and down-regulated (red) after HS among functional categories for tomato microspores. Proteins assigned to at least one category were considered and could be counted more than once. The Enriched GO terms for Process Ontology with FDR P $\leq 0.05$ in the Plant MetGenMap system. 
Citation: Li H, Zhu Y, Rangu M, Wu X, Bhatti S, et al. (2018) Identification of Heat-Induced Proteomes in Tomato Microspores Using LCM- Proteomics Analysis. Single Cell Biol 7: 173. doi:10.4172/2168-9431.1000173

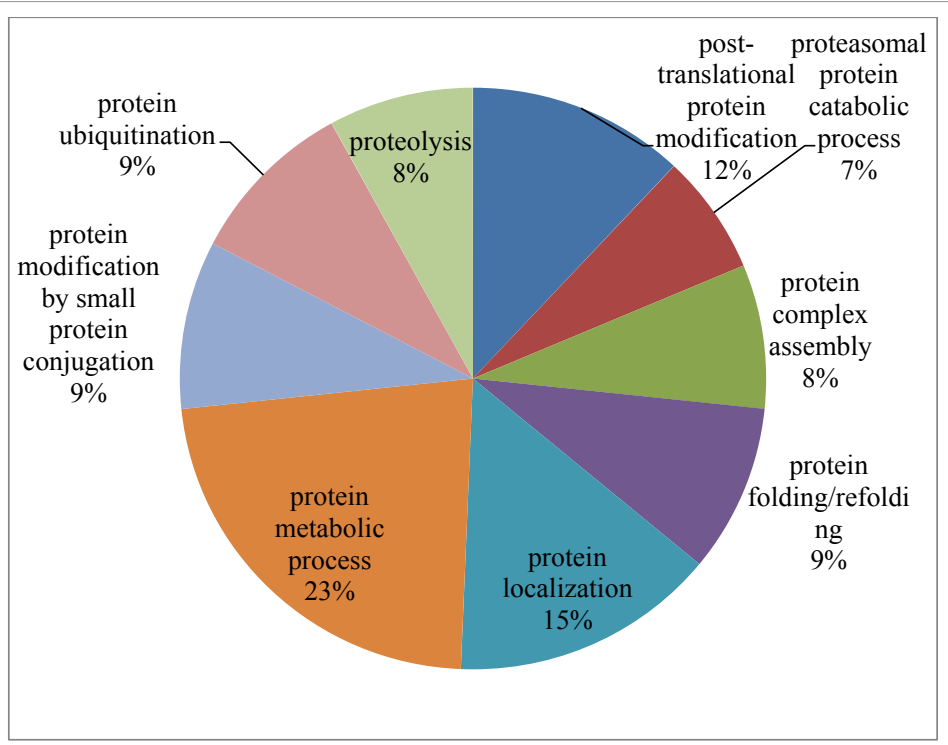

$3 \mathrm{~A}$

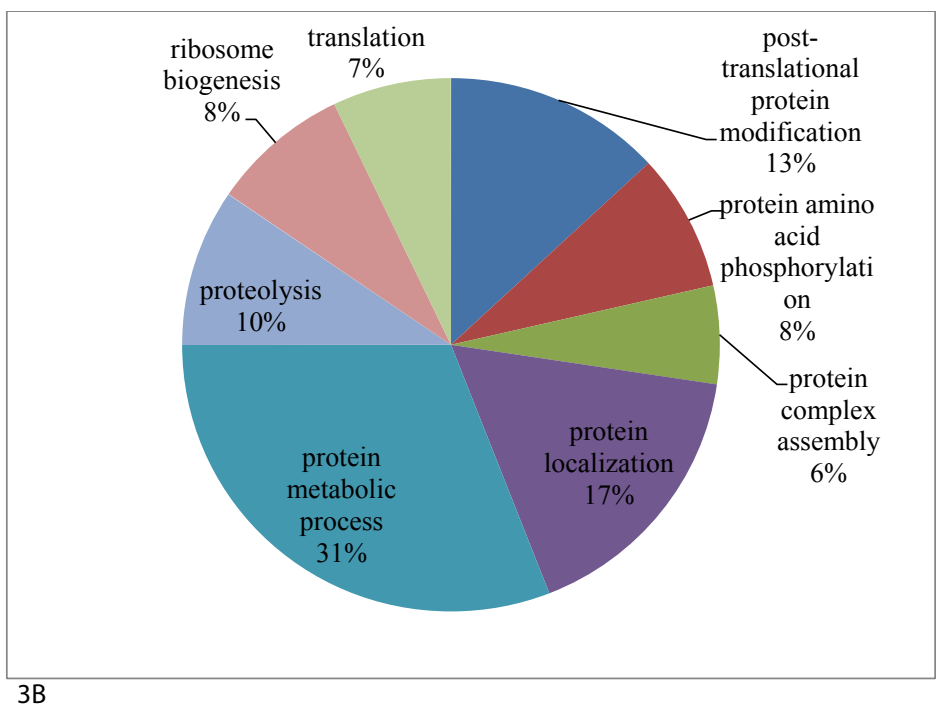

Figure 3: The enriched ontology processes affecting protein homeostasis in tomato microspores. Only the top 10 groups were selected. (3A) Heat-up-regulated SCPs, (3B) Heat-dn-regulated SCPs.

No. of proteins identfied

6018

Proteins quantified using tandem mass tags (TMT) reporter ion intensity of the labled tryptic peptides.

c. dProteins classified as Significantly Changed Proteins (SCPs) which have met the following criteria: ratio value (treated/control) higher than 2.0 standard deviation ( \pm $2 \mathrm{SD}$ ) derived from the normal distribution test, and proteins quantified with two or more unique peptides having a $\mathrm{P} \leq 0.05$ of ratio values (treated/control) using three replicates from each of the two conditions.

Table 1: Profile of proteins identified in heat-treated tomato microscopres.

Studies have shown that pollen and the surrounding anther tissues respond to heat stress at the transcriptome, proteome, and metabolome levels, similar to other plant cell types [13]. This proteomics study indicated that protein translation was reduced in tomato microspores under heat treatment conditions. Global down-regulation of de-novo protein biosynthesis was suggested to be an effective way to reduce protein flux into the folding machinery in the endoplasmic reticulum (ER) lumen as an effective mean to reduce ER stress [22,23]. The reduction of protein biosynthesis may have a similar role in the heat treated tomato microspores.

At the same time, selective mRNA translation becomes pivotal to maintain proper cell growth and protein homeostasis. In the tomato microspores, ten of the 35 HS-up-regulated SCPs are in the heat acclimation process. These tomato proteins include Hsp20, (Solyc07g045610, Solyc06g076540, Solyc06g076520, Solyc09g059210, 
Citation: Li H, Zhu Y, Rangu M, Wu X, Bhatti S, et al. (2018) Identification of Heat-Induced Proteomes in Tomato Microspores Using LCM- Proteomics Analysis. Single Cell Biol 7: 173. doi:10.4172/2168-9431.1000173

Page 6 of 9

\begin{tabular}{|c|c|c|c|c|}
\hline Ontology Process ${ }^{a}$ & $\begin{array}{c}\text { Protein } \\
\text { Accession }^{b}\end{array}$ & Ratio $^{c}$ & P-value $^{d}$ & Protein Description $^{e}$ \\
\hline \multirow{7}{*}{ DNA replication } & Solyc06g062690 & 1.4 & 0 & $\begin{array}{l}\text { Nucleosome assembly protein } \\
\text { 1-like protein } 4\end{array}$ \\
\hline & Solyc03g044350 & 1.8 & 0 & Chaperone dnaJ 3 \\
\hline & Solyc07g064970 & 1.5 & 0.01 & $\begin{array}{l}\text { Microtubule-associated protein } \\
\text { MAP65-1a }\end{array}$ \\
\hline & Solyc11g065190 & 1.5 & 0.02 & $\begin{array}{l}\text { Ubiquitin-conjugating enzyme } \\
\text { E2 H10 }\end{array}$ \\
\hline & Solyc05g050700 & 1.5 & 0.01 & $\begin{array}{l}\text { LRR receptor-like serine/ } \\
\text { threonine-protein kinase, RLP }\end{array}$ \\
\hline & Solyc03g112710 & 1.6 & 0.03 & SKP1-like 1 \\
\hline & Solyc10g055610 & 1.5 & 0.04 & SKP1-like 1 \\
\hline \multirow{5}{*}{$\begin{array}{l}\text { Regulation of DNA metabolic } \\
\text { process }\end{array}$} & Solyc01g087560 & 0.7 & 0.03 & 24-sterol C-methyltransferase \\
\hline & Solyc04g071690 & 0.6 & 0.02 & $\begin{array}{l}\text { Ribonuclease P protein subunit } \\
\text { p25 }\end{array}$ \\
\hline & Solyc06g073530 & 0.7 & 0.03 & Argonaute 4-like protein \\
\hline & Solyc03g097450 & 0.6 & 0.03 & $\begin{array}{l}\text { SWI/SNF complex subunit } \\
\text { SMARCC1 }\end{array}$ \\
\hline & Solyc07g049500 & 0.7 & 0.03 & Argonaute 4-like protein \\
\hline \multirow{10}{*}{ Chromosome organization } & Solyc08g006790 & 0.6 & 0.04 & Early nodulin-55-1 \\
\hline & Solyc03g119880 & 0.7 & 0.02 & Early nodulin-55-1 \\
\hline & Solyc03g097450 & 0.6 & 0.03 & $\begin{array}{l}\text { SWI/SNF complex subunit } \\
\text { SMARCC1 }\end{array}$ \\
\hline & Solyc07g049500 & 0.7 & 0.03 & Argonaute 4-like protein \\
\hline & Solyc11g062220 & 0.7 & 0.04 & $\begin{array}{l}\text { Novel protein containing a PHD- } \\
\text { finger domain }\end{array}$ \\
\hline & Solyc05g013740 & 0.7 & 0.01 & Coilin \\
\hline & Solyc03g095720 & 0.7 & 0.01 & $\begin{array}{c}\text { Transcription elongation factor, } \\
\text { TFIIS }\end{array}$ \\
\hline & Solyc12g010000 & 0.4 & 0.03 & Early nodulin-55-1 \\
\hline & Solyc10g005280 & 0.6 & 0.02 & $\begin{array}{l}\text { Pentatricopeptide repeat- } \\
\text { containing protein }\end{array}$ \\
\hline & Solyc06g073530 & 0.7 & 0.03 & Argonaute 4-like protein \\
\hline \multirow{2}{*}{$\begin{array}{l}\text { G2/M transition of mitotic cell } \\
\text { cycle }\end{array}$} & Solyc03g117630 & 1.6 & 0.01 & Heat shock protein 70 \\
\hline & Solyc04g011440 & 1.4 & 0.01 & Heat shock protein 70 \\
\hline \multirow{4}{*}{ Anaphase } & Solyc11g065190 & 1.5 & 0.02 & $\begin{array}{l}\text { Ubiquitin-conjugating enzyme } \\
\text { E2 H10 }\end{array}$ \\
\hline & Solyc10g055610 & 1.5 & 0.04 & SKP1-like 1 \\
\hline & Solyc07g064970 & 1.5 & 0.01 & $\begin{array}{l}\text { Microtubule-associated protein } \\
\text { MAP65-1a }\end{array}$ \\
\hline & Solyc $05 g 050700$ & 1.5 & 0.01 & $\begin{array}{l}\text { LRR receptor-like serine/ } \\
\text { threonine-protein kinase, RLP }\end{array}$ \\
\hline \multirow{4}{*}{ Interphase of mitotic cell cycle } & Solyc10g055610 & 1.5 & 0.04 & SKP1-like 1 \\
\hline & Solyc04g011440 & 1.4 & 0.01 & Heat shock protein 70 \\
\hline & Solyc06g062690 & 1.4 & 0 & $\begin{array}{l}\text { Nucleosome assembly protein } \\
\text { 1-like protein } 4\end{array}$ \\
\hline & Solyc03g117630 & 1.6 & 0.01 & Heat shock protein 70 \\
\hline \multirow{8}{*}{ M phase } & Solyc11g065190 & 1.6 & 0.02 & $\begin{array}{l}\text { Ubiquitin-conjugating enzyme } \\
\text { E2 } \mathrm{H} 10\end{array}$ \\
\hline & Solyc05g050700 & 1.5 & 0.01 & $\begin{array}{c}\text { LRR receptor-like serine/ } \\
\text { threonine-protein kinase, RLP }\end{array}$ \\
\hline & Solyc03g112710 & 1.6 & 0.03 & $\begin{array}{l}\text { E3 ubiquitin ligase, SCF } \\
\text { complex, Skp subunit }\end{array}$ \\
\hline & Solyc07g064970 & 1.5 & 0.01 & $\begin{array}{l}\text { Microtubule-associated protein } \\
\text { MAP65-1a }\end{array}$ \\
\hline & Solyc10g055610 & 1.6 & 0.04 & $\begin{array}{l}\text { E3 ubiquitin ligase, SCF } \\
\text { complex, Skp subunit }\end{array}$ \\
\hline & Solyc03g117630 & 1.6 & 0.01 & Heat shock protein 70 \\
\hline & Solyc04g011440 & 1.4 & 0.01 & Heat shock protein 70 \\
\hline & Solyc04g015270 & 1.5 & 0.02 & Glycosyltransferase \\
\hline
\end{tabular}


Citation: Li H, Zhu Y, Rangu M, Wu X, Bhatti S, et al. (2018) Identification of Heat-Induced Proteomes in Tomato Microspores Using LCM- Proteomics Analysis. Single Cell Biol 7: 173. doi:10.4172/2168-9431.1000173

Page 7 of 9

\begin{tabular}{|c|c|c|c|c|}
\hline \multirow{7}{*}{ Mitosis } & Solyc11g065190 & 1.6 & 0.02 & $\begin{array}{l}\text { Ubiquitin-conjugating enzyme } \\
\text { E2 H10 }\end{array}$ \\
\hline & Solyc07g064970 & 1.5 & 0.01 & $\begin{array}{l}\text { Microtubule-associated protein } \\
\text { MAP65-1a }\end{array}$ \\
\hline & Solyc10g055610 & 1.6 & 0.04 & $\begin{array}{c}\text { E3 ubiquitin ligase, SCF } \\
\text { complex, Skp subunit }\end{array}$ \\
\hline & Solyc03g112710 & 1.6 & 0.03 & $\begin{array}{l}\text { E3 ubiquitin ligase, SCF } \\
\text { complex, Skp subunit }\end{array}$ \\
\hline & Solyc04g051350 & 0.7 & 0.01 & $\begin{array}{l}\text { Ribonucleoside-diphosphate } \\
\text { reductase }\end{array}$ \\
\hline & Solyc11g062220 & 0.7 & 0.04 & $\begin{array}{c}\text { Novel protein containing a PHD- } \\
\text { finger domain }\end{array}$ \\
\hline & Solyc02g068480 & 0.7 & 0 & $\begin{array}{l}\text { Ubiquitin carboxyl-terminal } \\
\text { hydrolase }\end{array}$ \\
\hline \multirow{4}{*}{ Spindle organization } & Solyc07g064970, & 1.5 & 0.01 & $\begin{array}{l}\text { Microtubule-associated protein } \\
\text { MAP65-1a }\end{array}$ \\
\hline & Solyc08g006790 & 0.6 & 0.01 & Early nodulin-55-1 \\
\hline & Solyc07g049500 & 0.7 & 0.03 & Argonaute 4-like protein \\
\hline & Solyc06g073530 & 0.7 & 0.03 & Argonaute 4-like protein \\
\hline \multirow{8}{*}{ Pollen development } & Solyc11g065190 & 1.5 & 0.02 & conjugating enzyme E2 H10 \\
\hline & Solyc01g090600 & 1.6 & 0.02 & $\begin{array}{l}\text { Chalcone synthase } 3 \text { protein } \\
\text { (pollen wall formation) }\end{array}$ \\
\hline & Solyc07g065770 & 1.6 & 0.03 & $\begin{array}{c}\text { ABC transporter } \mathrm{G} \text { family } \\
\text { member } 26\end{array}$ \\
\hline & Solyc06g082500 & 1.5 & 0 & $\begin{array}{c}\text { Solute carrier family } 35 \text { member } \\
\text { E3 }\end{array}$ \\
\hline & Solyc04g008780 & 1.6 & 0.02 & $\begin{array}{l}\text { Dihydroflavonol 4-reductase } \\
\text { (wall formation) }\end{array}$ \\
\hline & Solyc01g010900 & 1.8 & 0.01 & $\begin{array}{l}\text { Cytochrome P450 (pollen wall } \\
\text { formation) }\end{array}$ \\
\hline & Solyc03g051960 & 1.5 & 0 & $\begin{array}{c}\text { Fatty acyl coA reductase/Male } \\
\text { sterility }\end{array}$ \\
\hline & Solyc05g050700 & 1.5 & 0.01 & $\begin{array}{l}\text { LRR receptor-like serine/ } \\
\text { threonine-protein kinase, } \mathrm{RLP}\end{array}$ \\
\hline \multirow{6}{*}{ Pollen wall formation } & Solyc03g051960 & 1.5 & 0 & $\begin{array}{c}\text { Fatty acyl coA reductase/Male } \\
\text { sterility }\end{array}$ \\
\hline & Solyc01g010900 & 1.8 & 0.01 & Cytochrome P450 \\
\hline & Solyc04g008780 & 1.6 & 0.02 & Dihydroflavonol 4-reductase \\
\hline & Solyc07g065770 & 1.5 & 0.01 & $\begin{array}{l}\text { LRR receptor-like serine/ } \\
\text { threonine-protein kinase, RLP }\end{array}$ \\
\hline & Solyc06g082500 & 1.5 & 0 & $\begin{array}{c}\text { Solute carrier family } 35 \text { member } \\
\text { E3 }\end{array}$ \\
\hline & Solyc01g090600 & 1.6 & 0.02 & Chalcone synthase 3 protein \\
\hline \multicolumn{5}{|c|}{$\begin{array}{l}{ }^{a} \text { Enriched GO of Ontology Process classified in the Plant MetGen Map system. } \\
\text { bUnigenes accession number in annotated tomato genome databases in Plant MetGen Map system. } \\
\text { ' } R \text { atio of protein abundance from heat treated to non-treated tissues estimated based on reporter ion intensity values in the Proteome Discoverer } 2.2 \text { (PD } 2.2 \text {, Thermo) } \\
\text { report. } \\
\text { dP value of the protein ratio between heat treated and non-treated groups (using three biological replicates each) in the Proteome Discoverer } 2.2 \text { (PD } 2.2 \text {, Thermo) } \\
\text { report. } \\
{ }^{e} \text { Annotated protein in the Plant MetGenMap system. }\end{array}$} \\
\hline
\end{tabular}

Table 2: Heat induced significantly changed proteins associated with pollen development.

1.8- 2.2-fold, $\mathrm{p}<0.05$ ), DnaJ (Solyc03g044350), Hsp70 (Solyc03g117630, Solyc04g011440, 1.4-1.6-fold, p<0.05), Hsp90 (Solyc06g036290, 1.5-fold, $\mathrm{p}=0.01$ ), and $\mathrm{ClpB}$ chaperone (Solyc03g115230, 1.4-fold, $\mathrm{p}=0.0001)$. These tomato HSPs are comprised of the cognate HSPs including HSP 70 (Hsc 70) [24,25] and the heat-inducible ClpB chaperone class [26,27]. These HSPs serve as chaperones for protein folding and refolding and thus have a critical role in maintaining proteome homeostasis throughout microspore and pollen development [13]. Therefore, these tomato HSPs, in particular the heat-inducible $\mathrm{ClpB}$ may have a key role for microspores to acquire heat tolerance and develop into viable pollen.

Heat stress affects composition in the primary and secondary metabolites (carbohydrates, lipids, proline, polyamines, glutathione, and flavonoids) [14,28]. A decrease in pollen viability is often associated with an alteration of metabolite contents such as soluble sugars and starch $[5,29]$. Sucrose produced in photosynthetic tissues is transported to anther, where it is converted to glucose and fructose under the action of acid invertase. Heat stress was shown to inhibit the acid invertase activity, which is in part responsible for decreased levels of soluble sugars in tomato anthers [7]. Tomato RNAi-lines with silencing of the Lin 5 gene, encoding for a homologous enzyme, showed pollen malformation and abortion [30]. In this study, we have identified several acid invertase ( $\beta$-D-fructofuranosidase) isoenzymes among the HS-dn-regulated SCPs (for instance, Solyc10g085640, Solyc09g010080, 0.36 -fold, $\mathrm{p}<0.01)$. We have also identified a fatty acyl-CoA reductase (FAR), which was annotated as a homolog to Male Sterility 2 (MS2). The FAR affects sporopollenin composition and reduced FAR activity leads 
to infertile pollen [31]. The identification of these SCPs supports the role of carbohydrate and lipid metabolites in pollen thermo-tolerance.

Heat also affects metabolism of secondary metabolites in many plant organs including pollens. A recent study using LC-MS platform showed that a short heat stress at $38^{\circ} \mathrm{C}$ leads to alteration of the secondary compound in tomato pollen, such as accumulation of flavonoids in the microspore [28]. Chalcone synthase catalyzes the initial step of flavonoid biosynthesis through the phenylpropanoid pathway. A lack of chalcone synthase activity leads to disruption of flavonoid synthesis and loss of pollen fertility [32]. The chalcone synthase 3 protein was induced in the heat treated tomato microspore (Solyc01g090600, 1.6fold, $\mathrm{p}=0.02)$. The dihydroflavonol 4-reductase (1.6-fold, $\mathrm{p}=0.02)$ and fatty acyl CoA reductase $(1.5$-fold, $p=0.02)$ also affect pollen wall formation $[31,33]$. These HS-upregulated SCPs may have a critical role in determining the fate of microspores under the stress conditions.

The uninucleate stage microspores undergo mitosis to develop into binucleate or trinucleate pollen grains. Several heat induced tomato SCPs are involved in repair of DNA damages (which occurs frequently under heat and other stresses), DNA replication, the mitotic cycles, and microspore cell wall loosening to allow pollen expansion after microspore mitosis [34]. These processes contained both HS upregulated or dn-regulated SCPs. Future work will focus on functional analysis of these SCPs in thermo-tolerance of the developing pollen.

\section{Conclusion}

This study has developed a LCM quantitative proteomics workflow which was used to identify cell-specific pollen proteomes associated with heat stress. Using the LCM, six replicate samples each containing approximately 60,000 tomato microspore cells were harvested. A onestep protein extraction procedure was developed where the LCMharvested pollens were directly subjected to the high pressure/vacuum extraction cycles. By eliminating tissue grinding and multiple steps of protein purification/precipitation, this protein extraction procedure has proven very effective in working with small amount of tissue such as in the case of LCM collected cells. The TMT-proteomics analysis of the LCM collected microspore proteins has led to the quantification of over 4000 proteins, and the identification of HS-induced SCPs that are involved in heat acclimation, proteome homeostasis, pollen coat formation, mitosis and other biological processes affecting pollen development under HS conditions.

\section{Ethics Approval and Consent to Participate}

Not applicable.

\section{Competing Interests}

The authors declare that they have no competing interests.

\section{Funding}

This project was supported by the Agriculture and Food Research Exploratory Award accession number 1009172, from the USDA National Institute of Food, and Agriculture, the USDA Evans-Allen Research Funds and ARS CRIS Projects 190721000-036/037-00D. ARS disclaimer: "Mention of trade names or commercial products in this publication is solely for the purpose of providing specific information and does not imply recommendation or endorsement by the U.S. Department of Agriculture."

\section{Author's Contributions}

Tomato plant treatments, LCM, protein preparation, TMT labeling, anther, and pollen microscopy, were performed by $\mathrm{YZ}, \mathrm{HL}, \mathrm{XBW}, \mathrm{MR}$, and SZ. TF assisted in the protein extraction, protein quantifications and labeling experiments as well as being responsible for various analytical experiments to guarantee the quality of the analysis. YY carried out all of the MS analysis, evaluated the data, and compiled the experimental results. SZ, SB, and HL prepared the manuscript. TWT and SZ developed the experimental design. Furthermore, TWT provided critical oversight for all the MS analysis, and contributed significantly to the drafting and revising of the manuscript. All authors read and approved the final manuscript.

\section{Acknowledgements}

The authors wish to thank Johanna M. Dela Cruz, and Carol J. Bayles of the Imaging Facility, Sheng Zhang of the Proteomics and Mass Spectrometry Facility of the Cornell University Institute of Biotechnology for expert technical assistance and helpful discussions.

\section{References}

1. United States Department of Agriculture (2016) Economic Research Service Tomato.

2. Geisenberg C, Stewart K (1986) Field crop management the tomato crop. The Tomato Crop (A scientific basis for improvement). Springer Dordrecht pp: 511-557.

3. Peet MM, Bartholomew M (1996) Effect of night temperature on pollen characteristics, growth, and fruit set in tomato (Lycopersicon esculentum Mill). J Amer Soc Hort Sci 121: 514-519.

4. Sakata T, Takahashi H, Nishiyama I, Higashitani A (2000) Effects of high temperature on the development of pollen mother cells and microspores in barley Hordeum vulgare. L J Plant Res 113: 395-402.

5. Pressman E, Peet MM, Pharr DM (2002) The effect of heat stress on tomato pollen characteristics is associated with changes in carbohydrate concentration in the developing anthers. Ann Bot 90: 631-636.

6. Sato S, Peet MM, Thomas JF (2002) Determining critical pre- and post-anthesis periods and physiological processes in Lycopersicon esculentum mill exposed to moderately elevated temperatures. J Exp Bot 53: 1187-1195.

7. Sato S, Kamiyama M, Iwata T, Makita N, Furukawa H, et al. (2006) Moderate increase of mean daily temperature adversely affects fruit set of Lycopersicon esculentum by disrupting specific physiological processes in male reproductive development. Ann Bot 97:731-738.

8. Echlin P, Godwin H (1968) The ultrastructure and ontogeny of pollen in Helleborus foetidus L II Pollen grain development through the callose specia wall stage. J Cell Sci 3: 175-186.

9. Chaturvedi P, Ghatak A, Weckwerth W (2016) Pollen proteomics: from stress physiology to developmental priming. Plant Reprod. 29: 119-132.

10. Chaturvedi $P$, Ischebeck T, Egelhofer V Lichtscheidl I, Weckwerth $W$, et al. (2013) Cell-specific analysis of the tomato pollen proteome from pollen mother cell to mature pollen provides evidence for developmental priming. J Proteome Res 12: 4892-4903.

11. Chaturvedi P, Doerfler H, Jegadeesan S, Ghatak A, Castillejo MA et al. (2015) Heat-treatment-responsive proteins in different developmental stages of tomato pollen detected by targeted mass accuracy precursor alignment (tMAPA). J Proteome Res 14: 4463-4471.

12. Ischebeck T, Valledor L, Lyon D, Gingl S, Nagler M, et al (2014) Comprehensive cell-specific protein analysis in early and late pollen development from diploid microsporocytes to pollen tube growth. Mol Cell Proteomics 13: 295-310.

13. Rieu I, Twell D, Firon N (2017) Pollen development at high temperature: from acclimation to collapse. Plant Physiol 173: 1967-1976.

14. Paupière MJ, van Heusden AW, Bovy AG (2014) The metabolic basis of pollen thermo-tolerance: Perspectives for breeding. Metabolites 4: 889-920.

15. Keller M, Consortium S, Simm S (2018) The coupling of transcriptome and proteome adaptation during development and heat stress response of tomato pollen. BMC Genomics pp: 1-20.

16. Santos MR, Bispo C, Becker JD (2017) Isolation of Arabidopsis pollen, sperm cells, and vegetative nuclei by fluorescence-activated cell sorting (FACS). In Plant Germline Development: Methods and Protocols. Springer New York, USA pp: 193-210.

17. Bokszczanin KL, Fragkostefanakis S (2013)Solanaceae Pollen Thermotolerance Initial Training Network (SPOT-ITN) Consortium, Perspectives on deciphering mechanisms underlying plant heat stress response and thermotolerance. Front Plant Sci 4: 1-20.

18. Zhu Y, Li H, Bhatti S, Zhou S, Yong Y (2016) Development of a laser capture microscope-based single-cell-type proteomics tool for studying proteomes of individual cell layers of plant roots. Hort Res 3: 16026. 
Citation: Li H, Zhu Y, Rangu M, Wu X, Bhatti S, et al. (2018) Identification of Heat-Induced Proteomes in Tomato Microspores Using LCM- Proteomics Analysis. Single Cell Biol 7: 173. doi:10.4172/2168-9431.1000173

Page 9 of 9

19. Zhou S, Okekeogbu I, Sangireddy S, Ye Z, Li H, et al. (2016) Proteome modification in tomato plants upon long-term aluminum treatment. J Proteome Res 15: 1670-1684.

20. Joung JG, Corbett AM, Fellman SM, Tieman DM, Klee HJ, et al. (2009) Plant metgenmap: an integrative analysis system for plant systems biology. Plant Physiol 151: 1758-1768.

21. Li Z, Palmer WM, Martin AP, Wang R, Rainsford F, et al. (2012) High invertase activity in tomato reproductive organs correlates with enhanced sucrose import into, and heat tolerance of, young fruit. J Exp Bot 63: 1155-1166.

22. Reid DW, Chen Q, Tay AS, Shenolikar S, Nicchitta CV, et al. (2014) The unfolded protein response triggers selective mRNA release from the endoplasmic reticulum. Cell 158: 1362-1374.

23. Ron D (2002) Translational control in the endoplasmic reticulum stress response. J Clin Invest 110: 1383-1388.

24. Craig EA (1985) The heat shock response. Critical Reviews in Biochemistry 18: 239-280.

25. Fragkostefanakis S, Mesihovic A, Simm S, Paupière M J, Hu Y, et al. (2016) HsfA2 controls the activity of developmentally and stress-regulated heat stress protection mechanisms in tomato male reproductive tissues. Plant Physiol 170: 2461-2477.

26. Duran EC, Weaver CL, Lucius AL (2017) Comparative analysis of the structure and function of $\mathrm{AAA}+$ motors $\mathrm{ClpA}, \mathrm{ClpB}$, and Hsp104: Common threads and disparate functions. Front Mol Biosci 4: 54

27. Lee S, Sowa ME, Watanabe YH, Sigler PB, Chiu W, et al. (2003) The structure of ClpB: A molecular chaperone that rescues proteins from an aggregated state. Cell 115: 229-240.

28. Paupière MJ, Müller F, Li H, Rieu I, Tikunov YM, et al. (2017) Untargeted metabolomic analysis of tomato pollen development and heat stress response. Plant Reprod 30: 81-94.

29. Firon N, Shaked R, Peet MM, Pharr DM, Zamski E, et al. (2006) Pollen grains of heat tolerant tomato cultivars retain higher carbohydrate concentration under heat stress conditions. Scientia Horti 109: 212-217.

30. Zanor MI, Osorio S, Nunes-Nesi A, Carrari F, Lohse M, et al. (2009) RNA interference of LIN5 in tomato confirms its role in controlling Brix content, uncovers the influence of sugars on the levels of fruit hormones, and demonstrates the importance of sucrose cleavage for normal fruit development and fertility. Plant Physiol 150: 1204-1218.

31. de Azevedo Souza C, Kim SS, Koch S, Kienow L, Schneider K, et al. (2009) A novel fatty acyl-CoA synthetase is required for pollen development and sporopollenin biosynthesis in Arabidopsis. Plant Cell Online 21: 507-525.

32. Mo Y, Nagel C, Taylor LP (1992) Biochemical complementation of chalcone synthase mutants defines a role for flavonols in functional pollen. Proc Nat Acad Sci USA 89: 7213-7217.

33. Tang LK, Chu H, Yip WK, Yeung EC, Lo C (2009) An anther-specific dihydroflavonol 4-reductase-like gene (DRL1) is essential for male fertility in Arabidopsis. New Phytologist 181: 576-587.

34. Hrubá P, Honys D, Twell D, Čapková V, Tupý J, et al. (2005) Expression of $\beta$-galactosidase and $\beta$-xylosidase genes during microspore and pollen development. Planta 220: 931-940. 